\title{
Learning Leadership from Donald Trump: What Not to Do
}

\author{
Hershey H. Friedman \\ City University of New York
}

\author{
Robert B. Fireworker \\ St. John's University
}

\begin{abstract}
Donald Trump has served as President of the United States for more than two years. His performance in office has provided many valuable lessons about leadership, especially about what not to do. This paper offers a partial list of leadership principles one can deduce from observing his leadership style. In addition, actual Trump quotations are provided.
\end{abstract}

Keywords: Negative Leadership, Leadership, Donald Trump, Intellectual Humility, Trump Quotations, Dunning-Kruger Effect.

\section{INTRODUCTION}

There is a serious leadership crisis today in the United States and much of the world (Annan, 2016; Pearse, 2018; Shahid, 2014; Veldsman, 2016; World Economic Forum, 2014). This crisis affects business, education, government, health care, and religion. People are distrustful of their leaders and the institutions they head. One CEO feels that "capitalism has been slowly committing suicide" by moving away from stakeholder capitalism and becoming the kind of selfish, predatory capitalism that only cares about top executives and investors (Leonhardt, 2019). This is causing intense political polarization and tribalism in the United States and other countries. According to a recent Gallup poll, $41 \%$ of Americans see the country as divided into "haves" and "have-nots" (Jones, 2019); 58\% disagree but this statistic is nothing to be proud of.

Veldsman (2016) believes that the leadership crisis is caused by five sources: "unable; unintelligent; immature; immoral and/or destructive leaders." He concludes that incompetent leaders "will destroy people, wreck economies and tear societies apart - irreparably." Ethical leaders, on the other hand, are guided by a strong moral compass and empowers others. They understand that leadership is not about fame, power, and wealth.

According to a World Economic Forum (2014) study:

Most people's understanding of a lack of values in leadership probably relates to the problem of leaders simply caring about their own interests, rather than being motivated by something more worthwhile. We expect leaders not to just stick to what they know, but to be driven by something that moves us forward and brings people together. And so, 
in reality, the concern is that there's not enough sharing of views, values and vision (World Economic Forum, 2014).

The presidency of Donald Trump, who came to the Oval Office from a lifetime in business, has served as an example of how a business leader should not behave. In his interviews with several business leaders, Damon (2004, pp.149-150) found that the majority were influenced by anti-mentors, people whom the leaders did not want to emulate. Damon (2004, p. 150) states: "People can learn new values throughout their lives, gaining knowledge from observing the catastrophes that befall themselves and others."

According to a study of leadership styles, many people learn more from negative example - i.e., negative morality - than from studying the correct way to behave (Oser, 2006).

Jeffrey T. Polzer, professor of human resource management at Harvard Business School, describes what makes a leader effective: the goal is "to surround yourself with talented people who have the most expertise, who bring different perspectives to the issue at hand. Then you foster debate and invite different points of view in order to reach a high-quality solution" (Stewart, 2018). This requires, of course, a leader with humility as well as the ability to find and keep competent people. None of this has been the case in the Trump White House.

The turnover rate in the Executive Office during the first two years of the Trump presidency was an astounding $65 \%$. Also, nearly $40 \%$ of the 705 leadership positions that require Senate confirmation have not been filled, and acting secretaries still head $25 \%$ of the administration's departments (Blinken, 2019). An unheard-of rate, this would be deadly in any organization. Jeffrey Pfeffer, professor of organizational behavior at Stanford University, notes that:

The most important thing you need as a chief executive is the ability to hire and retain talent. Trump said he'd get all these great people to work for him. But the rate of departures is unprecedented. Either he hired badly, or he hired well but couldn't retain them. Either way, this reflects badly on his leadership (cited in Stewart, 2018).

Presidential historian Doris Kearns Goodwin, author of, Leadership: In Turbulent Times, asserts that the following traits are associated with effective leadership: "humility, acknowledging errors, shouldering blame and learning from mistakes, empathy, resilience, collaboration, connecting with people and controlling unproductive emotions." She emphasizes that Trump lacks all of these qualities (Stewart, 2019). Many scholars believe that Donald Trump is a perfect example of the Dunning-Kruger effect. This is a cognitive bias where people with limited abilities or expertise are overconfident and believe they have superior abilities or expertise (Resnick, 2019). Interestingly, "This overestimation occurs as a result of the fact that they don't have enough knowledge to know they don't have enough knowledge" (Azarian, 2018).

The Trump presidency offers many valuable, negative lessons about leadership. Following is a partial list of them (don't try this at home):

1. The essence of good leadership is about loyalty, not competence. A good leader should surround himself or herself with incompetent people. The spotlight should always be on the leader. A good leader does not want competent people to steal some of his or her thunder. Moreover, incompetent people will be loyal to their leader since no one else would hire them.

2. A leader should surround himself with followers who will boost his ego. The job of followers is to constantly praise and flatter the leader.

3. Truth is whatever a leader claims it is. A great leader knows how to provide "alternative facts." To him or her, real news is not as believable or interesting as "fake news."

4. Being a good leader means never saying I am sorry. S/he always finds someone to blame. A great leader feels that the person who makes up the rules can never be wrong. S/he never 
admits to doing anything wrong or making a mistake; apologies and confessions are for losers; deny, deny, deny.

5. Good leaders never say "we." All that matters is "I." Success is about enriching oneself and screwing others. Always take the credit for anything positive that happens.

6. Never forgive anyone for a slight and never forget. If someone insults you, go for the kill. Totally crush and tear apart anyone who has the nerve to attack you.

7. Good leadership is about getting even. If someone treats you badly, you totally destroy her. Compassion is for losers. You can't be an effective leader if you swallow your pride. Use social media to destroy the reputation of any individual who is impudent enough to criticize the leader: only dumb, low IQ people criticize great leaders.

8. The best ways to influence people is to terrify them or lie to them. The road to success is paved with violence, brutality, and humiliation of others.

9. Fidelity is for women. A real man "shtups" any attractive woman, single or married, whether she likes it or not. This is why a true leader needs a good lawyer to help with coverups and confidential settlements.

10. If a woman disagrees with you, demean her looks and/or make fun of her bodily functions. Suggested terms of endearment: "horseface," "face of a pig," "crazed, crying lowlife," or "dog."

11. The country or organization is not important. Only the needs of the leader matters. In any case, the only legacy that matters is the amount of wealth the leader makes for himself, his family, and his friends. You are here for one reason: to enrich yourself, not to help others and improve the world.

12. The only moral compass a leader needs is one that points in one direction, to himself or herself.

13. A good leader is always certain of his opinions and never changes his/her mind. If you have to change direction, it is because people are too stupid to understand what you meant the first time.

14. Good leadership is about talking, not listening.

15. Whoever said "there is nothing so honorable as helping improve the lives of others" never experienced the joy of having an affair with a beautiful woman after buying expensive merchandise and stiffing the vendor.

16. A great leader never fails. One can learn more from failure than from success: Whom to blame, how to go bankrupt, and how to cover up.

17. Life is about give and take. A good leader takes, and everyone else gives.

18. Show me someone with humility and integrity, and I will show you a slimeball, wimp, and loser.

19. Only success matters, not truth. The winner is never asked if he was a man of integrity. Only losers talk about honor and integrity.

20. Effective leaders are those who know how to screw others.

21. Successful leaders ignore data and reports. All that matters is common sense and watching a lot of television.

\section{ACTUAL DONALD TRUMP QUOTES}

\section{On Truth and Honesty}

"I think the only difference between me and the other candidates is that I'm more honest and my women are more beautiful" (CBS News, 2018). 
"I dealt with Qaddafi. I rented him a piece of land. He paid me more for one night than the land was worth for two years, and then I didn't let him use the land. That's what we should be doing. I don't want to use the word 'screwed', but I screwed him. That's what we should be doing." (CBS News, 2018)

"Any negative polls are fake news, just like the CNN, ABC, NBC polls in the election. Sorry, people want border security and extreme vetting" (Jacobs, 2017).

"Fake news is at an all time high. Where is their apology to me for all of the incorrect stories???" (Spiering, 2017)

"I never asked Comey for Personal Loyalty. I hardly even knew this guy. Just another of his many lies. His "memos" are self serving and FAKE!" (Stableford, 2018)

"The claims [about my inappropriate conduct with women] are preposterous, ludicrous, and defy truth, common sense and logic. We already have substantial evidence to dispute these lies, and it will be made public in an appropriate way and at an appropriate time very soon" (Beckwith, 2016).

\section{Attacking Others}

"George Conway, often referred to as Mr. Kellyanne Conway by those who know him, is VERY jealous of his wife's success \& angry that I, with her help, didn't give him the job he so desperately wanted. I barely know him but just take a look, a stone cold LOSER \& husband from hell!" (Oprysko, 2019)

"Nasty son of a bitch" [President Trump about Charles Schumer] (Baker \& Grynbaum, 2019.

"I hope it's Biden. Biden was never very smart. He was a terrible student. His gaffes are unbelievable. When I say something that you might think is a gaffe, it's on purpose; it's not a gaffe. When Biden says something dumb, it's because he's dumb" [President Trump talking about running for a second term against Biden] (Baker \& Grynbaum, 2019).

"So sorry to hear the news about Jeff Bozo being taken down by a competitor whose reporting, I understand, is far more accurate than the reporting in his lobbyist newspaper, the Amazon Washington Post" [President Trump praising The National Enquirer for publishing an article about the Bezos' divorce] (Rutenberg, 2019).

"So funny to see little Adam Schitt (D-CA) talking about the fact that Acting Attorney General Matt Whitaker was not approved by the Senate, but not mentioning the fact that Bob Mueller (who is highly conflicted) was not approved by the Senate!" [President Trump described Democratic Congressman Adam Schiff of California as "little Adam Schitt" in a tweet] (Smith, 2018).

"What a stupid question that is, What a stupid question. But I watch you a lot. You ask a lot of stupid questions." [Trump's response to question by Abby Phillip of CNN. Her question: Did the president believe that Matthew Whitaker, acting attorney general, would "rein in" Mueller's investigation?] (Page, 2018).

"She doesn't know what the hell she's doing. She gets publicity and then she gets a pay raise, or she gets a contract with, I think, CNN. But she's very nasty and she shouldn't be. You've got to treat the White House and the office of the presidency with respect" [Trump describing April Ryan] (Page, 2018).

Trump about Democrats after Kavanaugh debacle. They have become "totally unhinged. "The Democrats have become too extreme and, frankly, they've become too dangerous to govern. They've gone wacko" (Baker, 2018).

"If anyone is looking for a good lawyer, I would strongly suggest that you don't retain the services of Michael Cohen!” (Davis \& Sullivan, 2018).

"When you give a crazed, crying lowlife a break, and give her a job at the White House, I guess it just didn't work out. Good work by General Kelly for quickly firing that dog!" (Graham, 2018; said about Omarosa Manigault Newman after her book was published).

"Lebron James was just interviewed by the dumbest man on television, Don Lemon. He made Lebron look smart, which isn't easy to do. I like Mike!" (Caron, 2018).

"Congresswoman Maxine Waters, an extraordinarily low IQ person, has become, together with Nancy Pelosi, the Face of the Democrat Party. She has just called for harm to supporters, of which there 
are many, of the Make America Great Again movement. Be careful what you wish for Max!" (Ralph, 2018).

"Robert De Niro, a very Low IQ individual, has received too many shots to the head by real boxers in movies. I watched him last night and truly believe he may be "punch-drunk." (Reuters, 2018).

"Meryl Streep, one of the most over-rated actresses in Hollywood, doesn't know me but attacked last night at the Golden Globes. She is a Hillary flunky who lost big. For the 100th time, I never "mocked" a disabled reporter (would never do that) but simply showed him "groveling" when he totally changed a 16 year old story that he had written in order to make me look bad. Just more very dishonest media!" (Samuelson, 2017)

“@Cher attacked@MittRomney. She is an average talent who is out of touch with reality. Like @Rosie O'Donnell, a total loser!" (McAfee, 2016)

.@Cher--I don't wear a "rug"-it's mine. And I promise not to talk about your massive plastic surgeries that didn't work. (Cohen, 2017)

"Rosie O'Donnell is disgusting - both inside and out. If you take a look at her, she's a slob. How does she even get on television? If I were running The View, I'd fire Rosie. I'd look her right in that fat, ugly face of hers and say, 'Rosie, you're fired.' We're all a little chubby but Rosie's just worse than most of us. But it's not the chubbiness - Rosie is a very unattractive person, both inside and out." (Frostenson \& Nelson, 2016)

"Amazing that Crooked Hillary can do a hit ad on me concerning women when her husband was the WORST abuser of woman in U.S. political history" (Lopez, 2016)

"Ariana Huffington is unattractive, both inside and out. I fully understand why her former husband left her for a man - he made a good decision." (CBS News, 2018).

"[The New York Times] They don't write good, they don't know how to write good. And I guess if they did, they're certainly not doing it." (Steleter, 2016)

"Look at that face [Carly Fiorina]. Would anyone vote for that? Can you imagine that, the face of our next President? I mean, she's a woman, and I'm not supposed to say bad things, but really, folks, come on. Are we serious?" (Cohen, 2017)

"I heard poorly rated@Morning Joe speaks badly of me (don't watch anymore). Then how come low I.Q. Crazy Mika, along with Psycho Joe, came to Mar-a-Lago 3 nights in a row around New Year's Eve, and insisted on joining me. She was bleeding badly from a face-lift. I said no!" (Claire, 2018)

"Slippery James Comey, a man who always ends up badly and out of whack (he is not smart!), will go down as the WORST FBI Director in history, by far!" (Fortin, 2018)

"He's [John McCain] not a war hero. He was a war hero because he was captured. I like people who weren't captured" (CBS News, 2018).

"While@BetteMidler is an extremely unattractive woman, I refuse to say that because I always insist on being politically correct" (CBS News, 2018).

"Cher is somewhat of a loser. She's lonely. She's unhappy. She's very miserable. And her soundenhanced and computer-enhanced music doesn't do it for me" (CBS News, 2018).

"When Mexico sends its people, they're not sending the best. They're sending people that have lots of problems and they're bringing those problems. They're bringing drugs, they're bringing crime. They're rapists and some, I assume, are good people, but I speak to border guards and they're telling us what we're getting” (CBS News, 2018).

"Lightweight Senator Kirsten Gillibrand, a total flunky for Chuck Schumer and someone who would come to my office "begging" for campaign contributions not so long ago (and would do anything for them), is now in the ring fighting against Trump. Very disloyal to Bill \& Crooked-USED!" (Stewart, 2017)

"We have to treat people that treat us well, we treat them well, people that treat us badly, we treat them much worse than they can imagine" (Kimbler, 2018). 


\section{Blaming Others}

"Democrats are the problem. They don't care about crime and want illegal immigrants, no matter how bad they may be, to pour into and infest our Country, like MS-13. They can't win on their terrible policies, so they view them as potential voters!" [Trump on the policy of separating immigrant families detained at the border] (Jackson, 2018)

"I hate the children being taken away, The Democrats have to change their law - that's their law" (Davis, 2018a).

"Such poor leadership by the Mayor of San Juan and others in Puerto Rico who are not able to get their workers to help." (Wallace, 2018)

"Very sad that the FBI missed all of the many signals sent out by the Florida school shooter. This is not acceptable. They are spending too much time trying to prove Russian collusion with the Trump campaign - there is no collusion. Get back to the basics and make us all proud!” (Merica \& Zeleny, 2018)

\section{On Apologies}

"I think apologizing's a great thing, but you have to be wrong. I will absolutely apologize, sometime in the hopefully distant future, if I'm ever wrong" (CBS News, 2018).

\section{The Press}

“The FAKE NEWS media (failing@nytimes,@NBCNews,@,ABC,@CBS,@CNN) is not my enemy, it is the enemy of the American People!" (Davis, 2018b)

\section{On the Wall}

"I will build a great wall - and nobody builds walls better than me, believe me - and I'll build them very inexpensively. I will build a great, great wall on our southern border, and I will make Mexico pay for that wall. Mark my words" (CBS News, 2018).

\section{Respect for Women}

"Great, now I can go after Horseface and her 3rd rate lawyer in the Great State of Texas." [Trump referred to pornographic actress Stephanie Clifford as "Horseface"] (Shear \& Sullivan, 2018)

"Wonderful looking while on the ice but up close and personal, she could only be described as attractive if you like a woman with a bad complexion who is built like a linebacker." [Description of German gold-medal winning Olympic ice skater Katarina Witt] (Cohen, 2017).

"Heidi Klum. Sadly, she's no longer a 10" [Heidi Klum, supermodel, who just turned 42] (CBS News, 2018). 2017)

"They'll walk up, and they'll flip their top, and they'll flip their panties." [Trump on women] (Cohen,

"You know I'm automatically attracted to beautiful - I just start kissing them. It's like a magnet. Just kiss. I don't even wait. And when you're a star they let you do it. You can do anything. Grab them by the $\mathrm{p}^{* * * *}$. You can do anything" (Claire, 2018).

"You could see there was blood coming out of her eyes [Megyn Kelly], blood coming out of her wherever" (CBS News, 2018). 2017)

"If Hillary Clinton can't satisfy her husband what makes her think she can satisfy America?" (Cohen,

"All of the women on The Apprentice flirted with me - consciously or unconsciously. That's to be expected" (CBS News, 2018).

"Certain guys tell me they want women of substance, not beautiful models. It just means they can't get beautiful models" (Dowd, 2015).

"You know, it doesn't really matter what [the media] write as long as you've got a young and beautiful piece of ass" (CBS News, 2018).

"Women have one of the great acts of all time. The smart ones act very feminine and needy, but inside they are real killers. The person who came up with the expression 'the weaker sex' was either very 
naive or had to be kidding. I have seen women manipulate men with just a twitch of their eye - or perhaps another body part." (CBS News, 2018).

"I sorta get away with things like that." [Donald Trump, on bursting into Miss Universe pageant dressing rooms.] (Kurtzman, 2017)

\section{Trump's Penis}

"My fingers are long and beautiful, as, it has been well documented, are various other parts of my body" (Claire, 2018).

"Look at those hands, are they small hands? And, [Republican rival Marco Rubio] referred to my hands: 'If they're small, something else must be small.' I guarantee you there's no problem. I guarantee." (Claire, 2018).

"I think Gloria would be very very impressed with [my penis]" (Frostenson \& Nelson, 2016).

\section{The Humility of Donald Trump}

"I've never had any trouble in bed, but if I'd had affairs with half the starlets and female athletes the newspapers linked me with, I'd have no time to breathe" (CBS News, 2018).

"Part of the beauty of me is that I am very rich" (CBS News, 2018).

"My IQ is one of the highest - and you all know it! Please don't feel so stupid or insecure; it's not your fault" (CBS News, 2018).

"I think I am actually humble. I think I'm much more humble than you would understand" (Claire, 2018).

"I know more about ISIS than the generals do. Believe me" (Claire, 2018).

"Show me someone with no ego and I'll show you a big loser" (ShortList, 2018).

"I'm intelligent. Some people would say I'm very, very, very intelligent" (ShortList, 2018).

"I say, not in a braggadocios way, I've made billions and billions of dollars dealing with people all around the world" (Shortlist, 2018).

"Happy New Year to all, including to my many enemies and those who have fought me and lost so badly they just don't know what to do. Love!" (Claire, 2018).

"Our country is in serious trouble. We don't have victories anymore. We used to have victories, but we don't have them. When was the last time anybody saw us beating, let's say China, in a trade deal? I beat China all the time. All the time" (CBS News, 2018).

"I'm the most successful person ever to run for the presidency, by far. Nobody's ever been more successful than me. I'm the most successful person ever to run. Ross Perot isn't successful like me. Romney - I have a Gucci store that's worth more than Romney" (ShortList, 2018).

"I could stand in the middle of 5th Avenue and shoot somebody and I wouldn't lose voters" (Kurtzman, 2017).

"My administration, I think, has had the most successful first year in the history of the presidency" (Kimbler, 2018).

\section{On Racism}

"Our great African-American President hasn't exactly had a positive impact on the thugs who are so happily and openly destroying Baltimore" [In response to Baltimore riots that occurred in response to death of Freddie Gray while in police custody.] (Claire, 2018).

"Black guys counting my money! I hate it. The only kind of people I want counting my money are little short guys that wear yarmulkes every day" (Parham, 2015).

"I have a great relationship with the blacks. I've always had a great relationship with the blacks" (CBS News, 2018).

"Well, I do think there's blame -- yes, I think there's blame on both sides. You look at -- you look at both sides. I think there's blame on both sides. And I have no doubt about it, and you don't have any doubt about it either" [Trump on the white supremacists and neo-nazis who rallied in Charlottesville, Virginia] (Segarra, 2017). 
"I've been treated very unfairly by this judge. Now, this judge is of Mexican heritage. I'm building a wall, OK? I'm building a wall" [Donald Trump, accusing U.S. District Judge Gonzalo Curiel, a citizen born in Indiana, who is presiding over the fraud case against Trump University, of being biased against him because of his Mexican heritage.] (Kurtzman, 2017).

"There were people that were cheering on the other side of New Jersey, where you have large Arab populations. They were cheering as the World Trade Center came down." [False statement about 9/11]. (CBS News, 2018).

"Why are we having all these people from shithole countries come here?" (Scott, 2018).

\section{On Global Warming}

"In the beautiful Midwest, windchill temperatures are reaching minus 60 degrees, the coldest ever recorded. In coming days, expected to get even colder. People can't last outside even for minutes. What the hell is going on with Global Waming (sic)? Please come back fast, we need you!" - Tweet by Trump on January 28, 2019 (Goldstein, 2019).

"The concept of global warming was created by and for the Chinese in order to make U.S. manufacturing non-competitive" (CBS News, 2018).

\section{Miscellaneous}

"If you have a windmill anywhere near your house, congratulations, your house just went down 75 percent in value. And they say the noise causes cancer" (Trump telling fellow Republicans that wind turbines cause cancer; Greenberg, 2019).

"Since the founding of our nation, many of our greatest strides, from gaining our independence to abolition of civil rights to extending the vote for women, have been led by people of faith" [Trump's Freudian slip at National Prayer Breakfast; Cummings \& Fritze, 2019).

"The Florida Election should be called in favor of Rick Scott and Ron DeSantis in that large numbers of new ballots showed up out of nowhere, and many ballots are missing or forged. An honest vote count is no longer possible—ballots massively infected. Must go with Election Night!" (Williams, 2018).

"We cannot allow all of these people to invade our Country. When somebody comes in, we must immediately, with no Judges or Court Cases, bring them back from where they came. Our system is a mockery to good immigration policy and Law and Order. Most children come without parents..." (Rucker \& Weigel, 2018).

"I am totally in favor of vaccines. But I want smaller doses over a longer period of time. Same exact amount, but you take this little beautiful baby, and you pump--I mean, it looks just like it's meant for a horse, not for a child, and we've had so many instances, people that work for me. ... [in which] a child, a beautiful child went to have the vaccine, and came back and a week later had a tremendous fever, got very, very sick, now is autistic" (CBS News, 2018).

"If Ivanka weren't my daughter, perhaps I'd be dating her" (CBS News, 2018).

"We won with poorly educated. I love the poorly educated" (CBS News, 2018).

"China steals United States Navy research drone in international waters - rips it out of water and takes it to China in unpresidented act." [Donald Trump needs help with his English. The word he meant to say was unprecedented.] (Pengelly, 2016).

"When we declare our schools to be gun-free zones, it just puts our students in far more danger" (Kimbler, 2018). 


\section{CONCLUSION}

Gregory (2018) believes that the most prevalent type of incompetent leader is the absentee leader, a person who provides no leadership and lets subordinates do what they want without providing guidance. Ignoring subordinates can be destructive to an organization, but a Dunning-Kruger leader can be extremely dangerous for an organization or country. A key flaw in Trump's leadership style, as this paper shows, is his arrogance and overconfidence. Trump's behavior reflects much contemporary behavior. Lynch (2017) underscores the fact that the "defining trait of the age seems to be arrogance...the arrogance of thinking that you know it all and that you don't need to improve because you are just so great already." Lynch's (2017) conclusion is that we all need intellectual humility. This means that people, especially effective leaders, need to accept that none of us really know as much as we think to do. A good leader should recognize his or her various biases and limitations, and appreciate the importance of learning from the experiences of others. This, of course, means that we have to be receptive to what others have to say, even those whose opinions differ from our own.

Another failing of Trump's leadership style is his need to surround himself with bootlickers and sycophants rather than talented people. Kets de Vries (2018) declares:

It goes without saying that a culture of obsequiousness doesn't attract the best and the brightest - quite the opposite. Even more troublesome is that people who engage in flattery are often those with even darker personality traits - the opportunists, the lazy, the power-hungry, the greedy, even the psychopaths and sociopaths. The latter may view the people that crave flattery as a potential source of money, power, and influence. Such connivers take advantage of the fact that flattery has the power to influence, corrupt, undermine and deceive (Kets de Vries, 2018).

Jouet (2017) believes that America is having a "meltdown" and has become extremely polarized: It is becoming virtually impossible to compromise when one side not only suffers from overconfidence and arrogance but also bases its arguments on myths and nonsense; all the more so, if both sides act this way.

... One of the main obstacles to bridging polarization is not only that there's a major divide among Americans about their values, but also there's a major factual divide about a lot of these issues. For example, if people believe that climate change is a hoax or a myth, it's not possible to genuinely discuss solutions to the problem.

If people widely believe that undocumented immigrants are massively flowing into the country, that they are responsible for illegal voting in the millions - which is completely false - there can't be a more rational discussion about issues like immigration. Unless there is more of a common nucleus of facts over which to debate, it is going to be very difficult to bridge the divide. We see that's also a big factor in the current debate over health care reform, given the magnitude of falsehoods about the oppression of Obamacare and shaping ideas about the need for eviscerating the legislation entirely (Jouet, 2017).

Pearse (2018) cites research that indicates that humble leaders are the most effective. Argandoña (2015) also feels this way and avers that, contrary to what many executives believe, "the humble leader is precisely the person who is best qualified to transform his firm into a profitable, successful, and respected organization" 


\section{REFERENCES}

Annan, K. (2016, February 3). The world has a leadership crisis, not a knowledge crisis. Retrieved from https://www.linkedin.com/pulse/world-has-leadership-crisis-knowledge-kofi-annan

Argandoña, A. (2015). Humility in management. Journal of Business Ethics, 132(1), November, 63-71.

Azarian, B. (2018, August 22). The Dunning-Kruger effect may help explain Trump's support.

Psychology Today. Retrieved from https:/www.psychologytoday.com/us/blog/mind-in-themachine/201808/the-dunning-kruger-effect-may-help-explain-trumps-support

Baker, P., \& Grynbaum, M. M. (2019, February 6). Unscripted, president unleashes on rivals. New York Times, A18.

Baker, P. (2018, October 9). Trump, emboldened by Kavanaugh victory, assails 'unhinged' Democrats. New York Times. Retrieved from https://www.nytimes.com/2018/10/09/us/politics/trump-rallykavanaugh-iowa.html

Beckwith, R. T. (2016, October 13). Read Donald Trump's fiery speech calling accusations against him 'outright lies.' Time. Retrieved from http://time.com/4530588/donald-trump-sexual-allegationstranscripts/

Blinken, A. J. (2019, January 29). Trump team isn't ready for a real foreign crisis. New York Times, A23.

Caron, C. (2018, August 4). Trump mocks LeBron James's Intelligence and calls Don Lemon 'dumbest man' on TV. New York Times. Retrieved from https://www.nytimes.com/2018/08/04/sports/donald-trump-lebron-james-twitter.html

CBS News. (2018). 30 of Donald Trump's wildest quotes. cbsnews.com. Retrieved from https://www.cbsnews.com/pictures/wild-donald-trump-quotes/

Claire, M. (2018, January 29). The best Donald Trump quotes from that Piers Morgan interview $>$ Marie Claire. Retrieved from http://www.marieclaire.co.uk/entertainment/people/donald-trump-quotes57213

Cohen, C. (2017, July 14). Donald Trump sexism tracker: Every offensive comment in one place. Telegraph. Retrieved from https://www.telegraph.co.uk/women/politics/donald-trump-sexismtracker-every-offensive-comment-in-one-place/

Cummings, W., \& Fritze, J. (2019, February 7). President Trump's gaffe touts 'abolition of civil rights' at National Prayer Breakfast. USA Today. Retrieved from https://www.usatoday.com/story/news/politics/2019/02/07/trump-national-prayerbreakfast/2799508002/

Damon, W. (2004). The moral advantage: How to succeed in business by doing the right thing. San Francisco: Berrett-Koehler Publishers.

Davis, J. D. (2018a, June 16). Trump again falsely blames Democrats for his separation tactic. New York Times. Retrieved from https://www.nytimes.com/2018/06/16/us/politics/trump-democratsseparation-policy.html

Davis, W. P. (2018b, July 19). 'Enemy of the people': Trump breaks out this phrase during moments of peak criticism. New York Times. Retrieved from https://www.nytimes.com/2018/07/19/business/media/trump-media-enemy-of-the-people.html

Dowd, M. (2015, August 8). Trump the disrupter. New York Times. Retrieved from https://www.nytimes.com/2015/08/09/opinion/sunday/maureen-dowd-trump-the-disrupter.html

Davis, J. H., \& Sullivan, E. (2018, August 22). Trump praises Manafort, saying 'unlike Michael Cohen' he 'refused to break.' New York Times. Retrieved from https://www.nytimes.com/2018/08/22/us/politics/trump-cohenmanafort.html?action $=$ click\&module $=$ Top $\% 20$ Stories\&pgtype $=$ Homepage

Fortin, J. (2018, April 15). James Comey vs. President Trump: How it came to this. New York Times. Retrieved from https://www.nytimes.com/2018/04/15/us/politics/james-comey-interview.html

Frostenson, S. \& Nelson, L. (2016, October 8). 61 insults, 39 women: Trump's long history of misogyny. Vox. Retrieved from https://www.vox.com/2016/10/8/13211908/61-insults-39-women-trumphistory-misogyny 
Goldstein, J. (2019, January 29). Donald Trump ways 'we need global warming' as extreme cold weather approaches the Midwest. People. Retrieved from https://people.com/politics/donald-trump-needglobal-warming-extreme-cold-midwest/?

Graham, D. A. (2018). Trump escalates his attacks on Omarosa by calling her a 'dog.' Atlantic. Retrieved from https://www.theatlantic.com/politics/archive/2018/08/trump-omarosa-feud/567431/

Greenberg, J. (2019, April 8). Donald Trump's ridiculous link between cancer, wind turbines. Politifact. Retrieved from https://www.politifact.com/truth-o-meter/statements/2019/apr/08/donaldtrump/republicans-dismiss-trumps-windmill-and-cancer-cla/

Gregory, S. (2018, March 30). The most common type of incompetent leader. Harvard Business Review. Retrieved from https://hbr.org/2018/03/the-most-common-type-of-incompetent-leader

Jackson, D. (2018, June 19). President Trump continues to blame Democrats for his family separation approach on immigration. USA Today. Retrieved from https://www.usatoday.com/story/news/politics/2018/06/19/donald-trump-blames-democrats-hisfamily-separation-policy/713499002/

Jacobs, P. (2017, February 6). TRUMP: 'Any negative polls are fake news. Business Insider. Retrieved from http://www.businessinsider.com/trump-any-negative-polls-are-fake-news-2017-2

Jones, J. M. (2019, April 3). Majority rejects idea of haves, have-nots divide in U.S. Gallup. https://news.gallup.com/poll/248216/majority-rejects-idea-haves-nots-divide.aspx

Jouet, M. (2017, July 23). America the divided: Why the great melting pot is having a meltdown. Knowledge@Wharton. Retrieved from http://knowledge.wharton.upenn.edu/article/america-thedivided-why-the-great-melting-pot-is-having-a-meltdown/

Kets de Vries, M. F. R. (2018). Trump: A tragi-comedy. INSEAD Working Paper No. 2018/22/EFE. Available at SSRN: https://ssrn.com/abstract=3193844 or http://dx.doi.org/10.2139/ssrn.3193844

Kimbler, M. (2018, February 23). 16 jaw-droppingly stupid quotes Trump spewed at CPAC. Advocate. Retrieved from https://www.advocate.com/politicians/2018/2/23/16-jaw-droppingly-stupidquotes-trump-spewed-cpac

Kurtzman, D. (2017, September 1). Donald Trump's craziest quotes of all time. ThoughtCo. Retrieved from https://www.thoughtco.com/donald-trump-quotes-crazy-racist-idiot-2733864

Leonhardt, D. (2019, April 1). A C.E.O. scared for his country. New York Times, A21.

Lopez, G. (2016, October 13). Donald Trump's past tweets about rape and sexual misconduct seem even worse now Vox. Retrieved from https://www.vox.com/policy-andpolitics/2016/10/13/13270020/trump-sexual-assault-tweets

Lynch, M. P. (2017, June 5). Teaching humility in an age of arrogance. Chronicle Review. Retrieved from http://www.chronicle.com/article/Teaching-Humility-in-an-Age-of/240266

McAfee, L. (2016, January 28). Trump vs. basically everybody: A short history of the Donald's short-fuse feuds. People. Retrieved from http://people.com/celebrity/donald-trumps-most-famous-feudsfrom-rosie-odonnell-to-megyn-kelly/

Merica, D., \& Zeleny, J. (2018, February 19). Trump blames everyone but Russia. CNN.com. Retrieved from https://www.cnn.com/2018/02/18/politics/trump-blame-fbi-parkland-shooting-russiainvestigation/index.html

Oprysko, C. (2019, March 20). Trump calls George Conway a 'husband from hell' to top aide Kellyanne. Politico. Retrieved from https://www.politico.com/story/2019/03/20/trump-george-kellyanneconway-1228558

Oser, F. K. (2006). Learning from negative morality. Journal of Moral Education, July, 67-74. http://dx.doi.org/10.1080/0305724960250107

Page, C. (2018, November 13). Is President Trump a racist — or does he just act like one? Chicago Tribune. Retrieved from https://www.chicagotribune.com/news/opinion/page/ct-perspec-pagetrump-jim-acosta-cnn-yamiche-alcindor-april-ryan-abby-phillips-1114-20181113-story.html

Parham, J. (2015, July 24). The collected quotes of Donald Trump on "the Blacks." Gawker. Retrieved from http://gawker.com/the-collected-quotes-of-donald-trump-on-the-blacks-1719961925 
Pearse, C. (2018, November 7). 5 reasons why leadership is in crisis. Forbes. Retrieved from https://www.forbes.com/sites/chrispearse/2018/11/07/5-reasons-why-leadership-is-incrisis/\#701fdafb3aca

Pengelly, M. (2016, December 17). Donald Trump accuses China of 'unpresidented' act over US navy drone. Guardian.com. Retrieved from https://www.theguardian.com/usnews/2016/dec/17/donald-trump-china-unpresidented-act-us-navy-drone

Ralph, P. (2018, June 25). Trump calls Maxine Waters 'an extraordinarily low IQ person' in response to Waters' call to publicly harass Trump officials. Business Insider. Retrieved from https://www.businessinsider.com/trump-maxine-waters-an-extraordinarily-low-iq-person-intweet-2018-6

Resnick, (2019, January 31). An expert on human blind spots gives advice on how to think. Vox. Retrieved from https://www.vox.com/science-and-health/2019/1/31/18200497/dunning-krugereffect-explained-trump

Reuters. (2018, June 12). Trump calls De Niro 'very low IQ individual' for Tony Awards outburst. Reuters.com. Retrieved from https://www.reuters.com/article/us-awards-tonys-denirotrump/trump-calls-de-niro-very-low-iq-individual-for-tony-awards-outburst-idUSKBN1J82ZQ

Rucker, P. \& Weigel, D. (2018. June 24). Trump advocates depriving undocumented immigrants of dueprocess rights. Washington Post. Retrieved from https://www.washingtonpost.com/powerpost/trump-advocates-depriving-undocumentedimmigrants-of-due-process-rights/2018/06/24/dfa45d36-77bd-11e8-93cc6d3beccdd7a3_story.html?utm_term $=.6 \mathrm{de} 6 \mathrm{fb} 870775$

Rutenberg, J. (2019, January 15). In Trump's swipe at Bezos, sweet talk for former ally. New York Times, B1, B4.

Samuelson, k. (2017, January 9). Donald Trump slams 'over-rated' Meryl Streep after Golden Globes speech. Time. Retrieved from http://time.com/4628378/golden-globes-2017-donald-trump-merylstreep/

Scott, D. (2018, January 12). "Shithole" countries, Donald Trump's latest racist tirade, explained. Vox. Retrieved from https://www.vox.com/policy-and-politics/2018/1/12/16882840/donald-trumpshithole-daca

Segarra, L. M. (2017, August 15). Read the transcript of president Trump's 'blame on both sides' comments on Charlottesville. Time. Retrieved from http://time.com/4902144/donald-trumpcharlottesville-blame-both-sides-kkk-nazi/

Shahid, S. (2014, November 7). Why the world in 2015 faces a leadership crisis. World Economic Forum. Retrieved from https://www.weforum.org/agenda/2014/11/world-2015-faces-leadership-crisis/

Shear, M. D. \& Sullivan, E. (2018, October 17). 'Horseface,' 'Lowlife,' 'Fat, Ugly': How president demeans women. New York Times, A1, A17.

ShortList (2018). The 50 most ridiculous Trump quotes. Retrieved from https://www.shortlist.com/news/the-50-most-ridiculous-trump-quotes-ever/54443

Smith, A. (2018, November 18). Trump calls congressman Adam Schiff 'little Adam Schitt' in a tweet. NBC News. Retrieved from https://www.nbcnews.com/politics/donald-trump/trump-callscongressman-adam-schiff-little-adam-schitt-tweet-n937726

Spiering, C. (2017, June 13). President Donald Trump continued to condemn "fake news" on Twitter, accusing the media of getting the story wrong. Breitbart.com. Retrieved from http://www.breitbart.com/big-government/2017/06/13/trump-fake-news-all-time-high/

Stableford, D. (2018, April 15). 'I hardly even knew this guy': Trump lashes out at Comey in Sunday morning tweetstorm. Yahoo News. Retrieved from https://www.yahoo.com/news/hardly-evenknew-guy-trump-lashes-comey-sunday-morning-tweetstorm-140752704.html

Stelter, B. (2016, August 2). Donald Trump says The New York Times doesn't "write good." CNNMoney. Retrieved from http://money.cnn.com/2016/08/02/media/donald-trump-new-yorktimes/index.html 
Stewart, J. B. (2019, January 11). Why Trump's C.E.O. traits don't work in Washington. New York Times, B1, B5.

Stewart, J. B. (2018, March 1). Trump management style, year 2: See year 1. New York Times, Retrieved from https://www.nytimes.com/2018/03/01/business/trump-management-style-year-2-see-year1.html

Stewart, E (2017). Kirsten Gillibrand told Donald Trump to resign over sexual assault allegations. Trump responded with a sexist tweet. Vox. Retrieved from https://www.vox.com/policy-andpolitics/2017/12/12/16766466/donald-trump-kirsten-gillibrand

Veldsman, T. (2016, August 29). Global leadership is in crisis - it's time to stop the rot. The Conversation. Retrieved from https://theconversation.com/global-leadership-is-in-crisis-its-timeto-stop-the-rot-64495

Wallace, G. J. (2018, February 16). President Trump's response to mass tragedies: Blame the victims. Thehill.com. Retrieved from http://thehill.com/opinion/white-house/374232-president-trumpsresponse-to-mass-tragedies-blame-the-victims

Williams, J. (2018, November 12). Trump says Florida election 'should be called in favor of Rick Scott and Ron DeSantis' despite uncounted ballots. Newsweek.com. Retrieved from https://www.newsweek.com/trump-florida-election-favor-scott-desantis-despite-uncountedballots-1211931

World Economic Forum (2014). Top 10 trends of 2014: A lack of values in leadership. WEForum.org. Retrieved from http://reports.weforum.org/outlook-14/top-ten-trends-category-page/7-a-lack-ofvalues-in-leadership/ 